Article

\title{
White Spruce Plantations on Abandoned Agricultural Land: Are They More Effective as C Sinks than Natural Succession?
}

\section{Sylvie Tremblay * and Rock Ouimet}

Ministère des Ressources naturelles, Direction de la recherche forestière, 2700 Einstein St., Québec, QC G1P 3W8, Canada; E-Mail: rock.ouimet@mrn.gouv.qc.ca

* Author to whom correspondence should be addressed; E-Mail: sylvie.tremblay@mrn.gouv.qc.ca; Tel.: +1-418-643-7994; Fax: +1-418-643-2165.

Received: 16 October 2013; in revised form: 21 November 2013 / Accepted: 3 December 2013 / Published: 11 December 2013

\begin{abstract}
The objective of this study was to compare organic carbon (C) accumulation in plantations (PL) and natural succession (NS) established on fallow lands along a 50-year chronosequence in the eastern mixed forest subzone of Quebec (Canada). Above- and below-ground woody biomass were estimated from vegetation measurement surveys, and litter and soil (0-50 cm depth) $\mathrm{C}$ from samplings. At the year of abandonment, total $\mathrm{C}$ content of both PL and NS sites averaged $100 \pm 13 \mathrm{Mg} \mathrm{C}^{-1}$. Over 50 years, total C content doubled on NS sites and tripled on PL sites $\left(217.9 \pm 28.7\right.$ vs. $\left.285.7 \pm 31.0 \mathrm{Mg} \mathrm{ha}^{-1}\right)$ with respect to fallow land. On NS sites, the new C stocks accumulated entirely in the vegetation. On PL sites, $\mathrm{C}$ accumulated mostly in the vegetation and to a lesser extent in the litter, whereas it decreased by a third in the soil. As a result, the net $\mathrm{C}$ accumulation rate was $1.7 \pm 0.7 \mathrm{Mg} \mathrm{ha}^{-1} \mathrm{yr}^{-1}$ greater on PL sites than on NS sites over 50 years. By the 23rd year, PL sites became greater net $\mathrm{C}$ sinks than NS sites in the fallow lands of the study area, even with the loss of soil C.
\end{abstract}

Keywords: forest carbon sequestration; afforestation; white spruce; plantations; natural succession; abandoned agricultural land

\section{Introduction}

A global warming of $+1.8^{\circ} \mathrm{C}$ to more than $5{ }^{\circ} \mathrm{C}$ is projected by 2100 in northern North America, very likely due to increased concentrations of anthropogenic greenhouse gases [1], of which carbon 
dioxide $\left(\mathrm{CO}_{2}\right)$ is the most important. Fighting global warming involves reducing $\mathrm{CO}_{2}$ sources, but also increasing $\mathrm{CO}_{2}$ sinks. Converting treeless, previously non-forested areas into plantations (afforestation) is recognized by the Kyoto Protocol as a method to increase $\mathrm{CO}_{2}$ sinks [2], because trees can sequester $\mathrm{CO}_{2}$ from the atmosphere and store it in living and dead organic matter through plant photosynthesis [3]. But do plantations established on abandoned agricultural soils sequester more $\mathrm{CO}_{2}$ than would natural succession on the same sites? This fundamental question has rarely been answered in earlier studies of forest restoration after agricultural land abandonment, most of which addressed only either plantation or natural succession. Few have compared the two approaches regarding their potential for $\mathrm{C}$ sequestration, especially in northern regions like Canada.

In recent years, extensive areas of agricultural land have been abandoned in eastern North America, Europe, East Asia and South America [4], mainly due to "agricultural industrialization" or "agricultural restructuring" [5]. In eastern Canada (Ontario to Newfoundland), 35\% of farm grasslands were abandoned between 1951 and 1991 [6]. The abandoned agricultural lands were usually the least productive. In the province of Quebec, 100,000 ha of abandoned agricultural lands were surveyed between 1997 and 2007; 45\% of these were located in the Bas-Saint-Laurent region, which has a low agriculture potential [7].

Worldwide, more area of abandoned agricultural land is now being restored by tree plantations than by natural succession [8]. The most appropriate choice for forest restoration depends on the objectives pursued, land conditions and resource availability [9]. Objectives generally include recovery of composition, structure, natural habitat, ecosystem processes and services [10], especially carbon storage, regulation of climate and water flow, supply of clean water and maintenance of soil fertility.

If herbaceous vegetation persists for a long time before woody vegetation is established on abandoned agricultural lands, Cuesta et al. [11] recommend restoration by plantation in order to reduce soil erosion, increase biological diversity, and create carbon sinks. In other cases, natural regrowth can have many advantages over typical forest plantations for storing $\mathrm{C}$ : (1) it is much less expensive and does not require the intensive effort of planting; (2) it involves tree species which are naturally adapted to the site and should be more resilient to disturbances; and (3) it has the additional benefit of ultimately restoring mature vegetation which approximates the original vegetation, thus restoring ecosystems and biodiversity in fragmented landscapes [12]. Total annual $\mathrm{C}$ accumulation in natural succession forests on abandoned farmland can also be significant. For example, in Ontario, it represents approximately $5 \%$ of the annual anthropic $\mathrm{CO}_{2}-\mathrm{C}$ emissions [13]. That being said, tree plantation can complement natural succession by nursing the establishment of late-succession tree species and stopping site degradation [9].

The effectiveness of $\mathrm{C}$ plantations around the world to slow down atmospheric $\mathrm{CO}_{2}$ accumulation was quantified by van Minnen et al. [14], who compared the net ecosystem productivity (NEP) of plantations and natural succession that would otherwise grow in the same areas. The more the NEP of plantations surpassed that of natural succession, the more effectively plantations sequestrated C. On the basis of ecological and environmental constraints alone, tropical plantations were the most effective $\mathrm{C}$ sinks. Those in high latitudes were the least effective because of low growth rates. In various parts of Canada and Russia, NEP can remain lower in plantations than under natural succession for as long as 50 years [14]. Betts [15] and Schaeffer et al. [16] also question C plantations at high latitudes, arguing that the use of conifer seedlings can decrease the land albedo and increase 
temperature; the resulting biophysical feedback on climate could cancel out the low net $\mathrm{C}$ sequestration. Given this, van Minnen et al. [14] only recommend the establishment of C plantations at high latitudes if $\mathrm{C}$ sequestration is combined with other objectives, such as water protection and soil erosion control.

Considering that (1) $67 \%$ of the afforestation on private lands in Canada occurred in Quebec between 1990 and 2002 [17], (2) almost half of the abandoned agricultural land in Quebec was located in the Bas-Saint-Laurent region between 1997 and 2007 [7], and (3) we had already estimated $\mathrm{CO}_{2}$ sequestration in plantations established on abandoned agricultural lands of southern Quebec [18,19], we compared organic $\mathrm{C}$ sequestration in plantations (PL) and natural succession (NS) established on fallow lands along a 50-year chronosequence in the Bas-Saint-Laurent region, to verify whether the increase of $\mathrm{C}$ sinks justified the effort of planting in this region.

\section{Experimental Section}

\subsection{Study Area}

The study area is located in southeastern Quebec, between latitude $47^{\circ}$ and $48.5^{\circ} \mathrm{N}$, in the Eastern balsam fir (Abies balsamea [L.] Mill.)-yellow birch (Betula alleghaniensis Britton) bioclimatic subdomain [20] (Figure 1). The mean annual temperature ranges from 1 to $4{ }^{\circ} \mathrm{C}$ [21]. The growing season lasts 150-160 days [22]. Growth conditions are: 1250-1450 degree-days above $5{ }^{\circ} \mathrm{C}$, 250-300 mm precipitations during the growing season, and a cumulative vapour pressure deficit of 1050-1350 mbar $(1 \mathrm{mbar}=0.1 \mathrm{kPa})$ during the growing season [21]. The parent soil material originates from the Appalachian Mountains and is composed of sedimentary rocks, shales, sandstone, conglomerates and volcanites. Soils are generally deep, well-drained loam to sandy loam, and classified as orthic humo-ferric Podzols [23].

Figure 1. Location of plantation (PL) and natural succession (NS) established on fallow lands and sampled in the Bas-Saint-Laurent region in eastern Quebec, Canada.

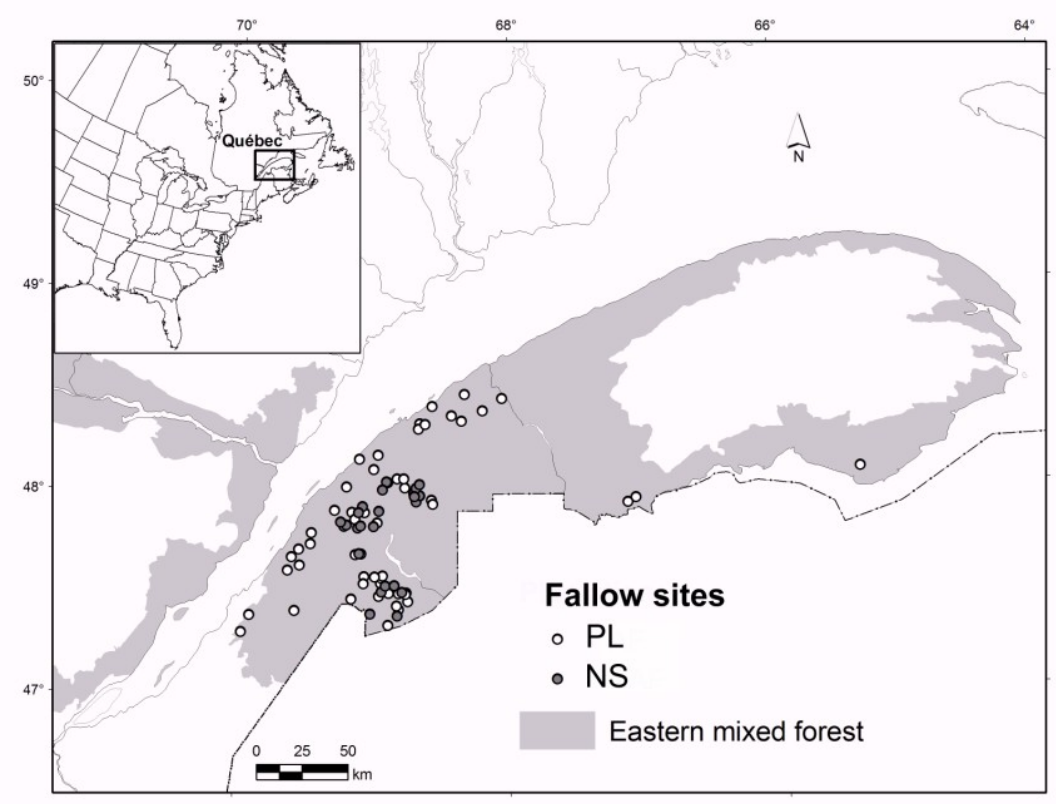




\subsection{The Chronosequence Approach}

To facilitate comparisons, PL and NS sites established on fallow lands were selected to be as similar as possible, except in age. Selection criteria were: size ( $>1$ ha of fallow land), soil order (Podzol), water regime (mesic), and soil texture (sand to sandy loam). Previous land use (cropland, grassland or pasture) remained unknown in most cases, and year of abandonment could often only be roughly estimated ( \pm 5 years) by consulting the current land owner. The chronosequence was composed of 54 PL sites ( 0 to 55 years old) and 27 NS sites ( 0 to 45 years old). The mean area of NS sites was 26 ha, except two sites of 200 ha. Since no significant effect of site preparation on C sequestration had been detected for PL sites in a previous study [18], this factor was not considered in the present study. Plantation sites had been planted with 4-year-old bareroot seedlings. Density of plantations was 2500 tree seedlings $\mathrm{ha}^{-1}$ for those aged 25 years or less, and ranged from 2217 to 2917 tree seedlings $\mathrm{ha}^{-1}$ for older ones. Plantations had never been thinned. The planted species was indigenous white spruce (Picea glauca [Moench] Voss), alone or mixed with up to $25 \%$ of (exotic) Norway spruce (Picea abies [L.] Karst), (indigenous) black spruce (Picea mariana [Mill.] BSP), (indigenous) white pine (Pinus strobus L.), (indigenous) red pine (Pinus resinosa Ait.), or (indigenous) tamarack (Larix laricina [Du Roi] K. Koch). Plantation sites were measured during the summer of 2004, and NS sites, during the summer of 2005.

\subsection{Tree and Shrub Measurements}

A single $400-\mathrm{m}^{2}$ (0.04-ha) plot was established on each site at a location chosen as representative of the site. The plot was circular $(R=11.28 \mathrm{~m})$ when tree density was low, and square $(20 \mathrm{~m} \times 20 \mathrm{~m})$ or rectangular $(10 \mathrm{~m} \times 40 \mathrm{~m})$ when tree density was high. A $10-\mathrm{m}$ buffer zone surrounded it. Because of differences in spatial distribution of vegetation, the measurement protocol differed between PL and NS sites and along the chronosequence.

On 0- to 5-year-old PL sites, all planted trees in the plot were measured for diameter at stump height (DSH) and height $(\mathrm{H})$, whereas unplanted trees and shrubs were measured in a $127-\mathrm{m}^{2}$ subplot $(R=6.36 \mathrm{~m})$ for diameter at breast height $(\mathrm{DBH})$ or $\mathrm{DSH}$, if $\mathrm{DBH}$ was not measurable. On 10 - to 55-year-old PL sites, all planted trees in the plot were measured for $\mathrm{DBH}$, and a subsample of 15 randomly chosen trees was measured for $\mathrm{H}$; unplanted vegetation was measured in a $40-\mathrm{m}^{2}$ subplot $(2 \mathrm{~m} \times 20 \mathrm{~m})$ for DBH or DSH.

On NS sites younger than 30 years, all trees and shrubs with $\mathrm{DBH} \geq 1 \mathrm{~cm}$ in the plot were measured for either DBH and $\mathrm{H}$, or DSH. On NS sites aged 30 years or more, all trees in the plot with a $\mathrm{DBH} \geq 9 \mathrm{~cm}$ were measured for $\mathrm{DBH}$ and $\mathrm{H}$, whereas trees and shrubs with $\mathrm{DBH}<9 \mathrm{~cm}$ were measured within a $50-\mathrm{m}^{2}$ subplot $(7.07 \mathrm{~m} \times 7.07 \mathrm{~m})$ for DBH or DSH.

Both live and dead trees were measured. DSH $(\mathrm{mm})$ was measured with an electronic vernier scale, and $\mathrm{DBH}(\mathrm{cm})$, with a diameter tape. $\mathrm{H}$ was measured with a ruler $(\mathrm{cm}$; trees or shrubs less than $3 \mathrm{~m}$ in height) or a vertex hypsometer ( $\mathrm{m}$; trees or shrubs more than $3 \mathrm{~m}$ in height). 


\subsection{Sampling of Litter and of Vegetation Shorter than $1.3 \mathrm{~m}$}

On PL sites, litter was sampled at four random locations in the $400-\mathrm{m}^{2}$ plot, using a $177-\mathrm{cm}^{2}$ punch. On NS sites, litter was sampled in four $1-\mathrm{m}^{2}$ locations established in the center of each quarter of the $400-\mathrm{m}^{2}$ plot. Litter included forest floor ( $\mathrm{L}$ and $\mathrm{F}$ layers and dead herbaceous plants) as well as live herbaceous plants and mosses, because they were all entangled. On NS sites, woody debris (diameter $>0.5 \mathrm{~cm}$ ) were also sampled with litter. Finally, on NS sites aged 30 years or more, aboveground biomass of saplings and shrubs shorter than $1.3 \mathrm{~m}$ was sampled separately from the litter in each $1-\mathrm{m}^{2}$ location. All samples were placed in paper bags and kept in cool conditions until they were transferred to a freezer $\left(-15^{\circ} \mathrm{C}\right)$ at the laboratory.

\subsection{Soil Sampling}

Two pits, randomly placed along a diagonal of the $400-\mathrm{m}^{2}$ plot, were dug in PL and NS sites. In each pit, soil was sampled at $10-\mathrm{cm}$ depth intervals down to $50 \mathrm{~cm}$ in PL sites, and at depths of 0-10 cm, 10-20 cm, 20-40 cm and 40-60 cm in NS sites. For each layer, two volumetric samples $\left(200 \mathrm{~cm}^{3}\right.$ each) and one bulk sample were taken. The $\mathrm{H}$ layer of the forest floor was included in the 0-10 cm sample. Also, in NS sites, soil was sampled down to $60 \mathrm{~cm}(0-10 \mathrm{~cm}, 10-20 \mathrm{~cm}, 20-40 \mathrm{~cm}$ and 40-60 cm) with a bucket auger at five locations, after removal of the $\mathrm{L}$ and $\mathrm{F}$ fractions of the organic layer. All samples were stored in cool conditions until they were transferred to a freezer $\left(-15^{\circ} \mathrm{C}\right)$ at the laboratory.

\subsection{Laboratory Analyses}

Once defrosted, saplings and shrubs, woody debris, herbaceous plants and mosses, and forest floor samples were oven-dried $\left(65^{\circ} \mathrm{C}, 48-72 \mathrm{~h}\right)$, weighed and ground $(250 \mu \mathrm{m}$ mesh). All soil samples were air-dried (48-72 h) and sieved through $2 \mathrm{~mm}$ mesh; subsamples were ground again through $250 \mu \mathrm{m}$ mesh. Volumetric soil samples were weighed before and after sieving through $2 \mathrm{~mm}$ mesh, in order to calculate bulk density as described by Federer et al. [24]. Total C content was determined on the basis of oven-dried mass $\left(105{ }^{\circ} \mathrm{C}\right)$ for all ground subsamples, following dry combustion with a LECO CR-412 carbon analyser. Total C content was presumed to equal organic $\mathrm{C}$ content, since the sampled soils were acid Podzols containing no calcareous minerals.

\subsection{Total C Content Estimation}

Organic C content was estimated for woody vegetation, litter and soil at each site. Biomass (anhydrous) of woody vegetation was computed using allometric equations reported in the Appendix A of Tremblay et al. [18] for aboveground biomass, and those from Li et al. [25] for coarse root biomass. Aboveground biomass of saplings and shrubs shorter than $1.3 \mathrm{~m}$ on NS sites aged 30 years or more, estimated from samples, was also included in the aboveground vegetation pool. A conversion factor of $0.50 \mathrm{~g} \mathrm{C}$ per $\mathrm{g}$ of anhydrous biomass was used for deciduous trees; the value was 0.49 for conifers [26]. Litter included the L and F layers, live or dead herbaceous plants and mosses, and woody debris (for NS sites); soil included the $0-50 \mathrm{~cm}$ and $\mathrm{H}$ layers. For NS sites, samples from the $40-60 \mathrm{~cm}$ soil depth were used to estimate soil $\mathrm{C}$ content in the $40-50 \mathrm{~cm}$ layer. Biomass of fine roots 
(diameter $<2 \mathrm{~mm}$ ) was not assessed as such in this study, since it was not possible to separate them all from the sampled soil; therefore, the soil $\mathrm{C}$ stocks may include some fine roots. Calculation of $\mathrm{C}$ stocks in soil and litter is described in Tremblay et al. [27].

\subsection{Statistical Analyses}

Stem abundance was analyzed by a quasi-general linear model (GLM) to correct for over dispersion, with vegetation type, species type (commercial, non-commercial) and number of years since abandonment as dependent variables. Vegetation composition was analyzed using the non-parametric multivariate analysis of variance procedure "adonis" of the "vegan" R package [28] with the default settings. Organic $\mathrm{C}$ concentrations in soils and $\mathrm{C}$ stocks in ecosystem compartments were fitted using a linear mixed-effects model, first by maximizing the log-likelihood (ML) with vegetation type (NS and PL), soil depth (ordered categorical variable), and age (continuous variable) as fixed effects; this model was used to allow for the homogenization of variance error that best fitted the data, based on comparisons of the Akaike (AIC) scores and residual plots. Individual sites were considered as random effects in the model. When the residual plots showed a non-linear pattern with age, the variable (age) ${ }^{2}$ was added to the model. The final models were refitted by maximizing the restricted log-likelihood (REML). Specific contrasts were built to compare vegetation types at 0 and 50 years. The analyses were performed with the "nlme" R package [29] and the R software v. 2.15 .2 [30].

\section{Results}

\subsection{Vegetation Composition and Density}

For the first 20 years after land abandonment, natural succession began with grass; shrubs and small trees $(\mathrm{DBH} \leq 9 \mathrm{~cm})$ then appeared between 20 and 30 years, followed by shrubs and taller trees $(\mathrm{DBH}>9 \mathrm{~cm})$ after 30 years. As a result, species composition was very different for NS and PL sites (Figure 2). The non-parametric multivariate analysis showed that $29.1 \%(P=0.001)$ of the difference in plant species composition could be explained by the two vegetation types. On the one hand, more commercial and non-commercial species were generally found on NS sites than on PL sites. Commercial species were trees, planted or not, with an economical value, whereas non-commercial species included non-planted trees, shrubs or herbs with no economical value. Picea glauca, the main planted indigenous species on PL sites, was also present in NS sites, but other Picea (including the non-indigenous Picea abies), Pinus and Quercus species were only found on PL sites. On the other hand, many small and tall brush species recorded on NS sites were absent from PL sites. Note that the N-fixing Alnus rugosa [DuRoi] Sprengel was more often observed on NS than on PL sites.

Tree planting strongly influenced the abundance of plant species which colonized the sites over time. Vegetation of PL sites was mainly composed of commercial species maintaining the same stem density over time (2340 stems ha $^{-1}$ on average; Figure 3 ); non-commercial species were present during the first years (average: 790 stems $^{-1}$ ) but then almost completely disappeared. By contrast, on NS sites, density of both commercial (average: $390 \mathrm{stems} \mathrm{ha}^{-1}$ ) and non-commercial species (average: 3350 stems $\left.\mathrm{ha}^{-1}\right)$ increased over time, the latter reaching a much higher level $\left(P_{\text {vegetation type } \times \text { years }}\right.$ $=0.024)$. 
Figure 2. Relative frequency of commercial and non-commercial plant species for plantation (PL) and natural succession (NS) established on fallow lands.

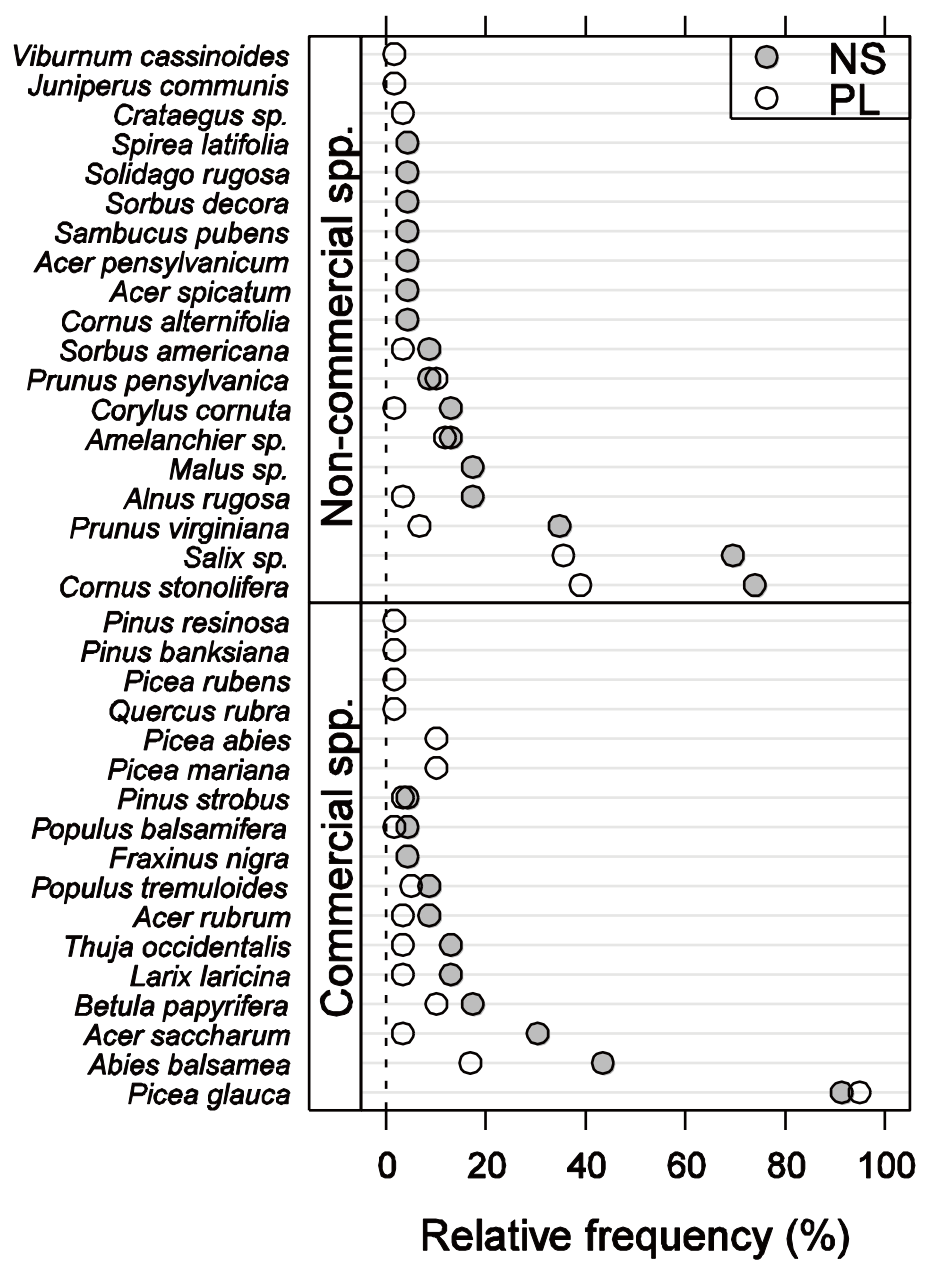

Figure 3. Stem abundance of commercial and non-commercial plant species for plantation (PL) and natural succession (NS) established on fallow lands. Dashed lines represent limits of the $95 \%$ confidence interval.

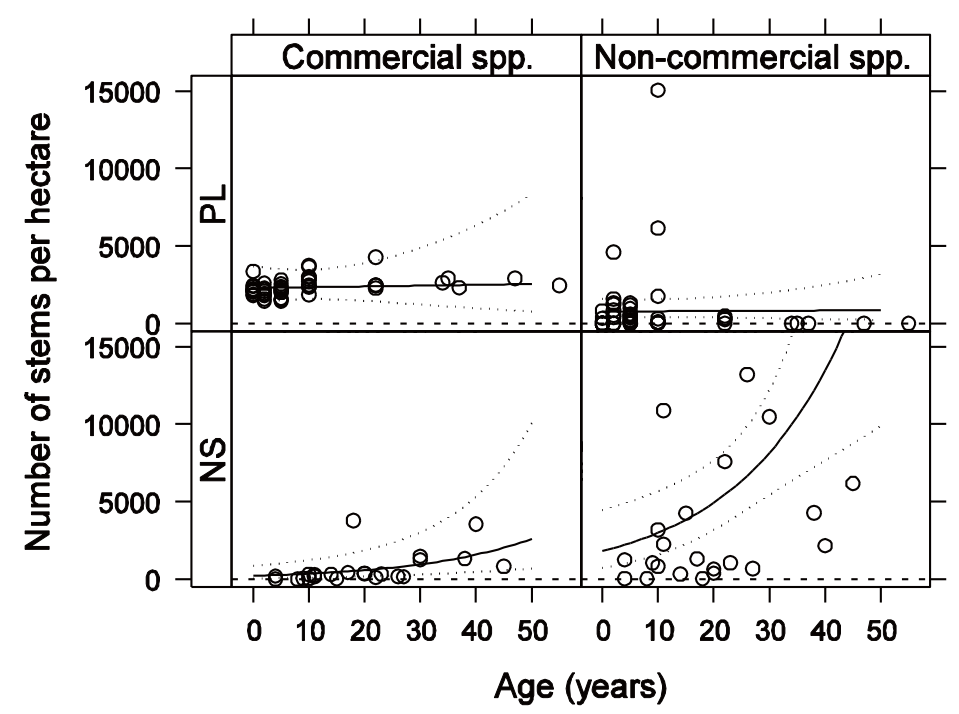




\subsection{Vegetation C Stock}

Plants (aboveground woody biomass and coarse roots) accumulated organic $\mathrm{C}$ following a non linear relationship with age over the 50 years $\left(P_{\text {age } 2}<0.001\right)$, and at a rate that was $2.6 \pm$ $0.4 \mathrm{Mg} \mathrm{C} \mathrm{ha}{ }^{-1} \mathrm{yr}^{-1}$ (mean $\left.\pm \mathrm{SE}\right)$ greater on PL sites than on NS sites $\left(P_{\text {vegetation type } \times \text { age }}<0.001\right.$; Figure 4B). As a result, after 50 years, the vegetation $C$ stock was 1.5 times greater on PL sites than on NS sites (214 vs. $84 \mathrm{Mg} \mathrm{C}^{-1}$, respectively; $P<0.001$ : Table 1).

Figure 4. Carbon (C) stocks $\left(\mathrm{Mg} \mathrm{ha}^{-1}\right)$ accumulated (A) in the whole ecosystem, and in the three compartments: (B) vegetation (aboveground woody biomass + coarse roots), (C) litter (litter + live or dead herbaceous plants and mosses + coarse woody debris), and (D) soil: 0 to $50 \mathrm{~cm}$, for the chronosequence of plantations (PL) and natural succession (NS) established on fallow lands. The lines show the model-predicted means and associated SE. The dots show C stocks at each site.

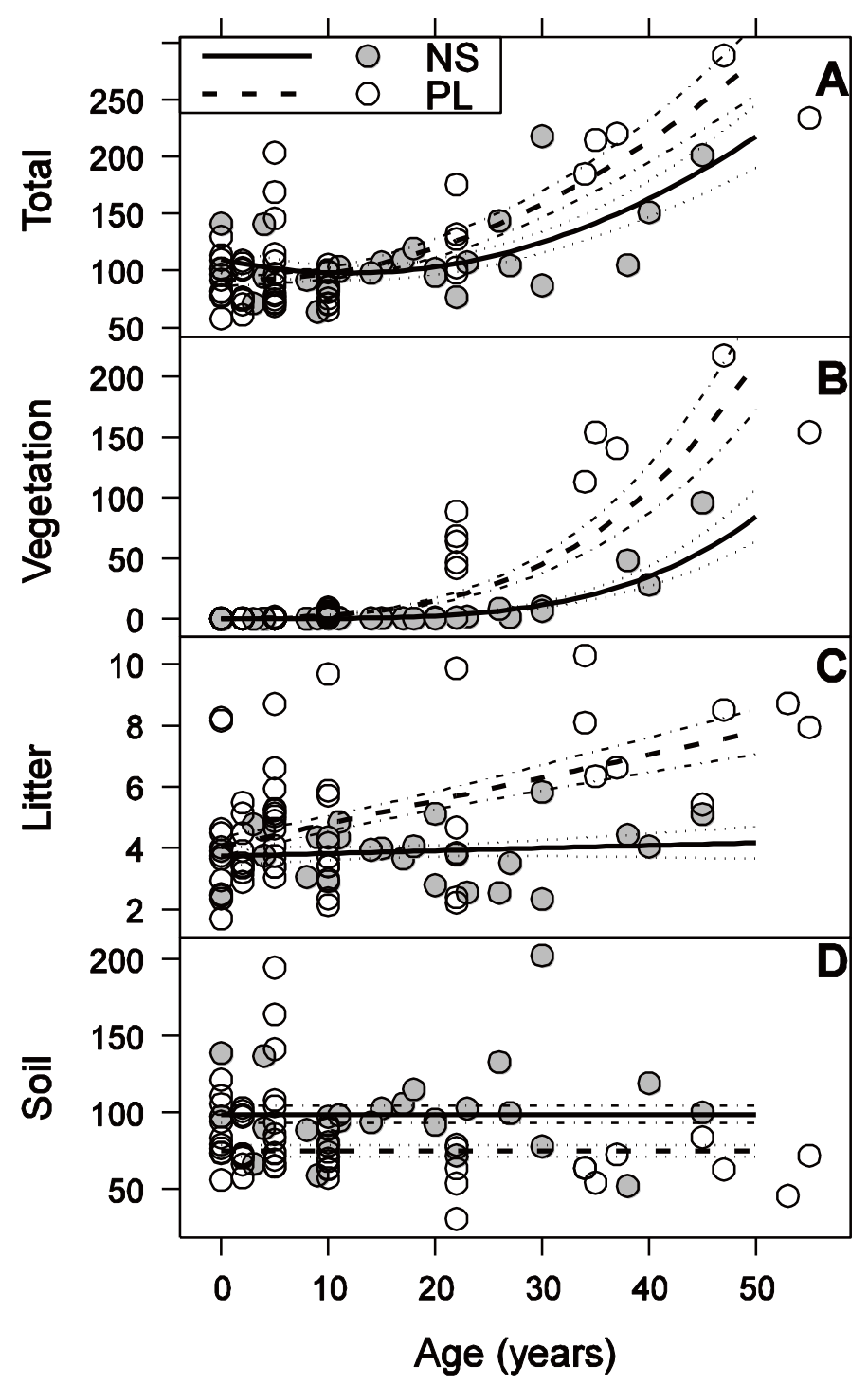


For both vegetation types, the sequestered $\mathrm{C}$ was mainly in vegetation, of which $92 \%$ was in the aboveground part on PL sites and $81 \%$ on NS sites (Table 1). The sequestered C in coarse roots was in the same range on PL and NS sites, but represented $8 \%$ and $19 \%$ of sequestered $\mathrm{C}$ in vegetation, respectively.

Table 1. Adjusted means of soil bulk density $\left(\mathrm{g} \mathrm{cm}^{-3}, 0-50 \mathrm{~cm}\right.$ depth) and $\mathrm{C}$ stocks ( $\mathrm{Mg} \mathrm{ha}^{-1}$, standard error in brackets) in the ecosystem compartments predicted at age 0 and 50 years according to fallow site type (NS: natural succession; PL: plantation). Soil: 0 to $50 \mathrm{~cm}$; litter: litter + herbaceous plants and mosses, live or dead, + coarse woody debris; vegetation: aboveground woody biomass and coarse roots. The probabilities of statistical difference between site types were assessed with a two-sided $t$ test.

\begin{tabular}{|c|c|c|c|c|c|c|c|c|c|}
\hline \multirow{2}{*}{\multicolumn{2}{|c|}{ Compartment }} & \multicolumn{4}{|c|}{ Age $=0$ years } & \multicolumn{4}{|c|}{ Age $=50$ years } \\
\hline & & NS & PL & Difference & $P$ & NS & PL & Difference & $P$ \\
\hline \multicolumn{2}{|c|}{ Bulk density } & $\begin{array}{c}0.975 \\
(0.031) \\
\end{array}$ & $\begin{array}{c}0.888 \\
(0.021) \\
\end{array}$ & $\begin{array}{c}0.086 \\
(0.031) \\
\end{array}$ & 0.005 & $\begin{array}{c}0.854 \\
(0.042)\end{array}$ & $\begin{array}{c}0.767 \\
(0.043) \\
\end{array}$ & 0.086 & 0.005 \\
\hline \multirow{5}{*}{$\begin{array}{c}\mathrm{C} \\
\text { stocks }\end{array}$} & $\begin{array}{c}\text { Soil } \\
(0-50 \mathrm{~cm})\end{array}$ & $\begin{array}{l}96.6 \\
(9.6)\end{array}$ & $\begin{array}{l}82.0 \\
(4.7)\end{array}$ & $\begin{array}{l}-14.5 \\
(10.7)\end{array}$ & 0.173 & $\begin{array}{c}97.9 \\
(15.6)\end{array}$ & $\begin{array}{c}53.9 \\
(10.6)\end{array}$ & $\begin{array}{l}-44.1 \\
(18.9)\end{array}$ & 0.020 \\
\hline & Litter & $\begin{array}{c}3.7 \\
(0.3)\end{array}$ & $\begin{array}{l}4.0 \\
(0.3)\end{array}$ & $\begin{array}{c}0.3 \\
(0.4)\end{array}$ & 0.490 & $\begin{array}{c}4.2 \\
(0.5)\end{array}$ & $\begin{array}{l}7.8 \\
(0.7)\end{array}$ & $\begin{array}{l}3.6 \\
(0.9)\end{array}$ & $<0.001$ \\
\hline & $\begin{array}{c}\text { Aboveground } \\
\text { vegetation }\end{array}$ & $\begin{array}{c}0.5 \\
(0.3)\end{array}$ & $\begin{array}{c}0.0 \\
(0.1)\end{array}$ & $\begin{array}{c}0.5 \\
(0.3)\end{array}$ & 0.067 & $\begin{array}{c}67.9 \\
(21.1)\end{array}$ & $\begin{array}{l}196.6 \\
(42.5)\end{array}$ & $\begin{array}{l}128.7 \\
(21.3)\end{array}$ & $<0.001$ \\
\hline & Coarse roots & $\begin{array}{c}0.0 \\
(0.0)\end{array}$ & $\begin{array}{c}0.0 \\
(0.0)\end{array}$ & $\begin{array}{c}0.0 \\
(0.0)\end{array}$ & 0.434 & $\begin{array}{l}16.3 \\
(2.7)\end{array}$ & $\begin{array}{l}16.9 \\
(2.7)\end{array}$ & $\begin{array}{c}0.6 \\
(0.2)\end{array}$ & 0.014 \\
\hline & Total & $\begin{array}{l}109.6 \\
(11.8)\end{array}$ & $\begin{array}{l}91.8 \\
(5.5)\end{array}$ & $\begin{array}{l}-17.8 \\
(11.8)\end{array}$ & 0.135 & $\begin{array}{l}217.9 \\
(28.7)\end{array}$ & $\begin{array}{l}285.7 \\
(31.0)\end{array}$ & $\begin{array}{c}67.8 \\
(28.1)\end{array}$ & 0.018 \\
\hline
\end{tabular}

\subsection{Litter C Stock}

The litter $\mathrm{C}$ stock increased more rapidly with time on PL sites than on NS sites $\left(P_{\text {vegetation type } \times \text { years }}\right.$ $=0.006$ ), resulting in an $86 \%$ difference after 50 years (Figure $4 \mathrm{C}$; Table 1). However, even after 50 years, the ecosystem's litter compartment remained small compared to the vegetation biomass and soil compartments.

\subsection{Soil C Stock}

No clear trend over time was present for soil $\mathrm{C}$ stock in the first $50 \mathrm{~cm}$ of soil tested as a whole $\left(P_{\text {vegetation type } \times \text { years }}=0.258\right)$. On average, $\mathrm{PL}$ sites contain $24.0 \pm 6.7 \mathrm{Mg}^{-1}$ less $\mathrm{C}$ than NS sites $(P<0.001$; Figure 4D). However, the contrast analysis reveals that after 50 years, soil C stocks on PL sites are $44.1 \pm 18.9 \mathrm{Mg} \mathrm{ha}^{-1}$ lower than on NS sites, and that this difference is statistically significant $(P=0.020$; Table 1). Compared to sites at age zero, this represents a $34 \%$ average loss of soil $\mathrm{C}$.

The examination of soil $\mathrm{C}$ concentrations and stocks according to depth revealed more details about these differences. Firstly, both variables tend to increase on NS sites but decrease on PL sites, though only in the first $30 \mathrm{~cm}$ of soil $(P \leq 0.097$; Figure 5). Secondly, the differences in soil $\mathrm{C}$ between PL and 
NS sites tend to decrease with soil depth. Finally, both organic $\mathrm{C}$ concentrations and $\mathrm{C}$ stocks decrease with soil depth $(P \leq 0.001$, Figure 5).

Figure 5. Soil $\mathrm{C}$ concentrations and stocks according to site age, fallow site type (plantation [PL] and natural succession [NS]), and soil depth (10-cm layers from 0-10 to 40-50 cm). Lines show model predictions and their SE; dots show site means.

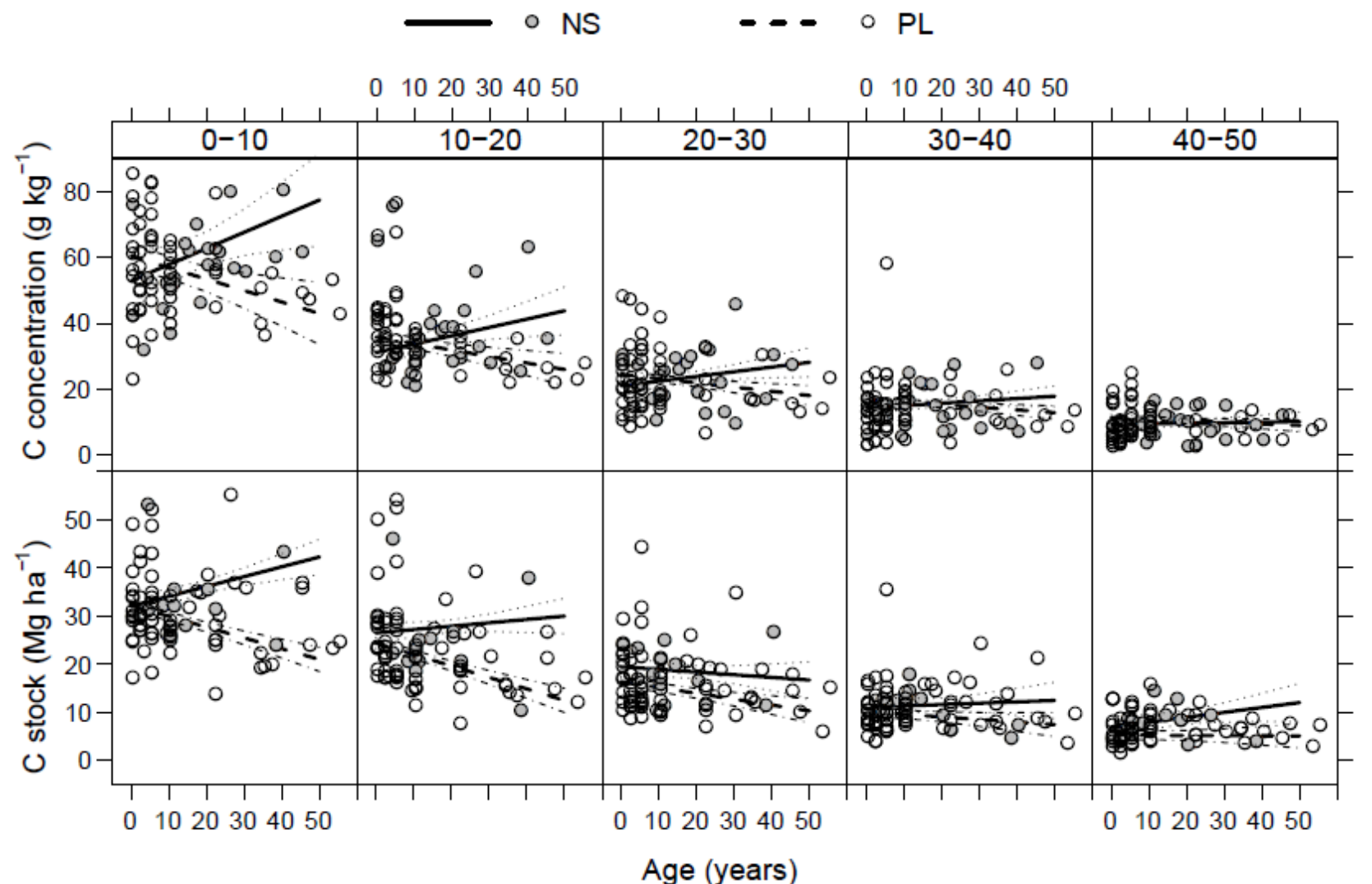

\subsection{Total C Stock}

The relationship between total organic $\mathrm{C}$ stocks in the whole system and age was quadratic during the 50 years $\left(P_{\text {age } 2}=0.001\right)$, with slightly different rates for the two vegetation types $\left(P_{\text {vegetation type } \times \text { years }}\right.$ $=0.019$; Figure 4A). At 50 years, on average, PL sites stored $31 \%$ more $\mathrm{C}$ in the ecosystem than NS sites $\left(P=0.018\right.$; Table 1). The calculated rate of $\mathrm{C}$ accumulation was $1.7 \pm 0.7 \mathrm{Mg} \mathrm{ha}^{-1} \mathrm{yr}^{-1} \mathrm{greater}$ on PL sites than on NS sites $(P=0.018$ : Table 1). According to the regression analysis, the ecosystem $\mathrm{C}$ stock in PL sites became statistically higher than in NS sites after 23 years $\left(\Delta \mathrm{C}_{\text {total }}\right.$ (PL-NS) at 23 years $\left.=+21.6 \pm 10.9 \mathrm{Mg} \mathrm{Cha}^{-1}, P=0.05\right)$.

The average $0-50 \mathrm{~cm}$ depth soil bulk density values differed between the two vegetation types $(P=0.007)$ and among site age $(P=0.021$; Table 1$)$. The interaction vegetation type $\times$ age was insignificant $(P=0.685)$. 


\section{Discussion}

\subsection{Vegetation}

After 50 years, vegetation was the dominant $\mathrm{C}$ sink on abandoned agricultural land. The sequestered $\mathrm{C}$ was mainly in aboveground vegetation. Sequestered C in coarse roots seemed proportionally higher on NS sites than on PL sites, probably because of the higher root:shoot ratio of shrubs compared to trees [31]. Though vegetation $\mathrm{C}$ stocks reached the levels in soils $(0-50 \mathrm{~cm})$ on NS sites and even exceeded them on PL sites, this $\mathrm{C}$ pool remains more vulnerable to disturbances than the soil C pool [32].

The mean sequestration rate in biomass of PL sites was about twice that of NS sites after 50 years. This agrees with the results of Anderson et al. [33], who estimated from 91 studies around the world that biomass accumulated, on average, 1.2 times faster in plantations than on naturally regenerating sites, following stand-clearing disturbances like fire or agriculture. The lower sequestration rate of NS sites is probably attributable to the 20 -year delay before natural succession establishment. Such delays have also been reported at higher and lower latitudes: 15-20 years in Latvia at $\sim 57^{\circ} \mathrm{N}$ [34], $10-42$ years in $\mathrm{UK}$ at $\sim 54^{\circ} \mathrm{N}$ [35], and 20-55 years in the Mediterranean region at $\sim 40^{\circ} \mathrm{N}[36,37$ ]. The distance from the seed stand is probably not the main explanation, since wind dispersal of seeds can occur over much larger distances. For example, birch seeds can travel over $1 \mathrm{~km}$ in open terrain during winter [38]. Ruskule et al. [34] rather suggest that, on rich soils, the development of a dense herbaceous vegetation cover can hinder the establishment of tree species. This explanation is consistent with the inhibition model of succession [39], and very likely applies to our study, since the soils were generally deep and well-drained, with a sandy to sandy loam texture, and host to a dense herbaceous plant cover on sites less than 20 years old.

There were generally more tree species on NS sites than on PL sites. Fifty years after agricultural land abandonment in a subtropical humid region of China, Zhang et al. [40] also found that the tree layer had greater species richness in secondary deciduous forests than in pine plantations. This was also the case for the herbaceous layer, but not for the shrub layer. This result suggests not only that plant biodiversity was greater on NS sites, but also that seed scattering by surrounding trees was not a problem. Also, the fact that many small and tall brush species recorded on NS sites were absent from PL sites suggest that the vegetation structure was more heterogeneous on NS sites than on PL sites.

\subsection{Litter}

Fifty years after land abandonment, litter $\mathrm{C}$ was $86 \%$ higher on PL sites than on NS sites. On the one hand, the higher $\mathrm{C}$ stock of PL litter might be due in part to the composition of conifer needles, which leads to a slower litter decomposition [41]. On the other hand, NS litter could have remained stable because of its more degradable leaves and of the 20 -year delay before natural succession development. 


\subsection{Soil}

Fifty years after land abandonment, mineral $\mathrm{C}$ stock in the first $30 \mathrm{~cm}$ of soil decreased on PL sites, but increased on NS sites. In accordance with our results, Zhang et al. [40] found a higher soil C concentration in natural succession sites compared to plantation sites, 50 years after land abandonment. In both studies, the effect of planting was confounded with that of tree species, since planted seedlings were conifers whereas natural succession forests were mainly composed of broadleaf species. According to these authors, soil $\mathrm{C}$ varied between the two scenarios, partly because of differences in stem growth and litter cycling between the planted conifers and the natural succession deciduous forest. However, the continually decreasing C stock in mineral soil of our PL sites, even 50 years after white spruce plantation, suggests that the planned rotation of our PL sites should be longer than 50 years to allow them to reach a net gain of $\mathrm{C}$ in the mineral soil.

Previous land use, which was unknown or highly unsure in our study, is also a determinant factor on subsequent soil organic C dynamics [42]. Soil C stocks generally increase on depleted ex-croplands, and remain unchanged or decrease on ex-grasslands and ex-pastures with the progressive disappearance of their abundant root litter [42-46]. For example, Guo et al. [47] observed, in an afforested pasture with pines, that the loss of soil $\mathrm{C}$ was positively correlated with the mortality volume of fine roots. However, fine root dynamic (production and mortality) was not measured in our study. Nevertheless, our study sites were probably ex-grasslands or ex-pastures, because the Bas-Saint-Laurent region has a low agricultural potential, and because the Ministry of Natural Resources of Quebec provided free tree seedlings only to owners of lands with low potential for agriculture [7]. Consequently, the hypothesis of decreased fine root litter after pasture or grassland afforestation with conifer could be plausible in our study.

For a same previous land use change, natural succession could sequester more $\mathrm{C}$ in soil than plantation, because of the lack of soil disturbance during the change of land use and the creation of an aboveground (and possibly underground) multi-storey structure which maximizes resource exploitation [43]. In our PL sites, no difference in soil $\mathrm{C}$ sequestration had been observed previously among the controls or site preparation treatments [18]. However, the abundance and diversity of non-commercial species on NS sites suggests the presence of a multi-storey structure. Among non-commercial species, shrubs can play a key role, since their higher root:shoot ratio compared to trees [31] allows a higher $C$ input to soil by root litter [45]. Finally, the higher frequency of Alnus rugosa on NS sites could have facilitated soil $\mathrm{C}$ sequestration by providing extra nitrogen input from bio-nitrogen fixation [48]. The increase in soil $\mathrm{N}$ under $\mathrm{N}_{2}$ fixers is often concomitant with an increase in soil C [49].

Finally, for both PL and NS sites, organic C stocks changed only in superficial soil layers. This result is consistent with other studies [14,40]. These layers are also the most subject to changes in bulk density, since litter decomposition and consequent humification can decrease soil bulk density over time [50]. When this happens, the final $\mathrm{C}$ stock is underestimated, which falsely indicates a decrease in $\mathrm{C}$ over time. To avoid the problem, final $\mathrm{C}$ stocks should be multiplied by the initial:final density ratio in order to compare $\mathrm{C}$ content of a same soil mass [51]. In our study, the corrected difference in soil C stocks between NS and PL sites in the 0-50 cm layer after 50 years would amount to around $49 \mathrm{Mg} \mathrm{ha}{ }^{-1}$ rather than $44 \mathrm{Mg} \mathrm{ha}^{-1}$ on average. However, this correction would not change our 
conclusion, namely that 50 years after agricultural land abandonment, $\mathrm{C}$ stocks were higher on NS sites than on PL sites.

\subsection{Total}

The estimated total sequestration rate was $3.9 \pm 0.6 \mathrm{Mg} \mathrm{Cha}^{-1} \mathrm{yr}^{-1}$ (or $14 \pm 2 \mathrm{Mg} \mathrm{CO}_{2} \mathrm{ha}^{-1} \mathrm{yr}^{-1}$ ) for PL sites and $2.2 \pm 0.6 \mathrm{Mg} \mathrm{Cha}^{-1} \mathrm{yr}^{-1}$ (or $8 \pm 2 \mathrm{Mg} \mathrm{CO}_{2} \mathrm{ha}^{-1} \mathrm{yr}^{-1}$ ) for NS sites. The net $\mathrm{CO}_{2}$ sequestration rate of $\mathrm{Pl}$ sites, compared to NS sites, was thus $1.7 \pm 0.7 \mathrm{Mg} \mathrm{C} \mathrm{ha}^{-1} \mathrm{yr}^{-1}$ (or $6 \pm$ $2 \mathrm{Mg} \mathrm{CO}_{2} \mathrm{ha}^{-1} \mathrm{yr}^{-1}$ ). As Quebec's anthropic GES emissions of 2011 was $80 \mathrm{Mt} \mathrm{CO}_{2}$ eq. [52] and as the total area of abandoned agricultural available for forest conversion in Quebec in 2006 was 120,000 ha [53], planting white spruce on these areas would be equivalent to $0.1 \%$ of Quebec's anthropic GES emissions of 2011. These calculations demonstrate that, at latitudes similar to our study, vast areas would be needed to be equivalent to annual Quebec's anthropic GES emissions, because not only of the low growth rates of the vegetation, but also of the low net $\mathrm{CO}_{2}$ sequestration rate of PL sites, compared to NS sites.

\section{Conclusions}

Over 50 years, the $\mathrm{C}$ accumulation rate on PL sites was $1.71 \pm 0.72 \mathrm{Mg} \mathrm{ha}^{-1} \mathrm{yr}^{-1}$ greater than on NS sites on abandoned, low-productivity agricultural lands of eastern Quebec. As a result, 31\% more total $\mathrm{C}$ was stored on PL sites during this period, mainly in vegetation biomass. Aboveground vegetation accounted for $92 \%$ of $\mathrm{C}$ sequestration in vegetation on PL sites and $81 \%$ on NS sites. The lower C sequestration rate on NS sites was probably due to the 20 -year delay before the appearance of natural succession. From year 23 onwards, white spruce plantations generated net $\mathrm{C}$ sinks more effectively than natural broadleaf succession. However, the additional $\mathrm{C}$ pools on PL sites (aboveground vegetation mostly, and litter to a lesser extent) are more vulnerable than soil to disturbances like insects, fire and harvesting, especially under changing climate.

Recommendations:

(1)To promote long-term climate change mitigation, PL sites should have planned rotations of more than 50 years for them to reach a net gain of $\mathrm{C}$ in the mineral soil, since soil $\mathrm{C}$ stocks of PL sites were still decreasing after 50 years.

(2)Longer-term studies on spruce PL sites should be continued to determine the moment when mineral soil starts to sequestrate $\mathrm{C}$, and down to which depth. Also, measuring fine root production and mortality would allow estimation of the importance of this soil $\mathrm{C}$ input.

(3)Although NS sites sequester less C, they still represent an interesting option because of other advantages, such as a lower cost, a higher plant biodiversity, and a larger soil $\mathrm{C}$ sink in the 0-30 cm layer.

\section{Acknowledgments}

The authors thank Jean-Philippe Mottard, forest technician, for supervising the NS site inventory and for taking pictures; Simon Carmichael and Marylin Yargeau, students, for help during field sampling; Pascal Desjardins, Fernand Gosselin, Jean-Sébastien Joannette and Gilles Thébeau, forest 
technicians, for their occasional help in the field; Carol de Blois and his team at the chemistry laboratory of the Direction de la recherche forestière, for sample preparation and chemical analyses; and Geneviève Picher for carrying out some of the statistical analyses. The authors also thank Johanne Claveau (Direction de la recherche forestière) and Marc-André Lechasseur (Agence régionale de mise en valeur des forêts privées du Bas-Saint-Laurent) for selecting NS sites, Denise Tousignant for editing the manuscript, and the three anonymous reviewers for their constructive comments. This publication was funded by the research project 02003074 approved by the Fonds de recherche québécois sur la nature et les technologies (FRQNT).

\section{Conflicts of Interest}

The authors declare no conflict of interest.

\section{References}

1. Solomon, S.; Qin, D.; Manning, M.; Chen, Z.; Marquis, M.; Averyt, K.B.; Tignor, M.; Miller, H.L. Climate Change 2007: The Physical Science Basis; Contribution of Working Group I to the Fourth Assessment Report of the Intergovernmental Panel on Climate Change, 2007; Cambridge University Press: Cambridge, UK, 2007.

2. Metz, B.; Davidson, O.R.; Bosch, P.R.; Dave, R.; Meyer, L.A. Climate Change 2007: Mitigation of Climate Change; Contribution of Working Group III to the Fourth Assessment Report of the Intergovernmental Panel on Climate Change, 2007; Cambridge University Press: Cambridge, UK, 2007.

3. Lal, R. Soil carbon sequestration impacts on global climate change and food security. Science 2004, 304, 1623-1627.

4. McLauchlan, K. The nature and longevity of agricultural impacts on soil carbon and nutrients: A review. Ecosystems 2006, 9, 1364-1382.

5. Rey Benayas, J.M.; Martins, A.; Nicolau, J.M.; Schulz, J.J. Abandonment of agricultural land: An overview of drivers and consequences. CAB Rev. Perspect. Agri., Vet. Sci., Nutr. Nat. Resour. 2007, 2, 057:1-057:14.

6. Parson, H.E. Regional trends of agricultural restructuring in Canada. Can. J. Reg. Sci. 1999, 22, 343-356.

7. Vouligny, C.; Gariépy, S. Abandoned Farmland in Quebec-Status and Development Options; Agriculture and Agri-Food Canada: Ottawa, Canada, 2008.

8. Food and Agriculture Organization (FAO). State of the World's Forests 2011; FAO: Rome, Italy, 2011. Available online: http://www.fao.org/docrep/013/i2000e/i2000e00.htm (accessed on 10 May 2013).

9. Lugo, A.E. The apparent paradox of re-establishing species richness on degraded lands with tree monocultures. For. Ecol. Manage. 1997, 99, 9-19.

10. Chazdon, R.I. Beyond deforestation : Restoring forests and ecosystem services on degraded lands. Science 2008, 320, 1458-1460. 
11. Cuesta, B.; Rey Benayas, J.M.; Gallardo, A.; Villar-Salvador, P.; Gonzales-Espinosa, M. Soil chemical properties in abandoned Mediterranean cropland after succession and oak reforestation. Acta Oecologica 2012, 38, 58-65.

12. Fensham, R.J.; Guymer, G.P. Carbon accumulation through ecosystem recovery. Environ. Sci. Policy 2009, 12, 367-372.

13. Foote, R.L.; Grogan, P. Soil carbon accumulation during temperate forest succession on abandoned low productivity agricultural lands. Ecosystems 2010, 13, 795-812.

14. Van Minnen, J.G.; Strengers, B.J.; Eickhout, B.; Swart, R.J.; Leemans, R. Quantifying the effectiveness of climate change mitigation through forest plantations and carbon sequestration with an integrated land-use model. Carbon Balance Manage. 2008, 3, 3; doi:10.1186/1750-0680-3-3.

15. Betts, R.A. Offset of the potential carbon sink from boreal forestation by decreases in surface albedo. Nature 2000, 408, 187-190.

16. Schaeffer, M.; Eickhout, B.; Hoogwijk, M.; Strengers, B.; van Vuuren, D.; Leemans, R.; Opsteegh, T. $\mathrm{CO}_{2}$ and albedo climate impacts of extra-tropical carbon and biomass plantations. Global Biogeochem. Cycles 2006, 20, doi:10.1029/2005GB002581.

17. White, T.M.; Kurz, W.A. Afforestation on private land in Canada from 1990 to 2002 estimated from historical records. For. Chron. 2005, 81, 491-497.

18. Tremblay, S.; Périé, C.; Ouimet, R. Changes in organic carbon storage in a 50 year white spruce plantation chronosequence established on fallow land in Quebec. Can. J. For. Res. 2006, 36, 2713-2723.

19. Ouimet, R.; Tremblay, S.; Périé, C.; Prégent, G. Ecosystem carbon accumulation following fallow farmland afforestation with red pine in southern Quebec. Can. J. For. Res. 2007, 37, 1118-1133.

20. Saucier, J.-P.; Bergeron, J.-F.; Grondin, P.; Robitaille, A. Les régions écologiques du Québec méridional (3e version): un des éléments du système hiérarchique de classification du territoire mis au point par le ministère des Ressources naturelles du Québec, Québec, Canada; Supplément de l'Aubelle; Gouvernement du Québec: Québec, Canada, 1998.

21. Noël, J. Relations entre la végétation, le milieu physique, les perturbations naturelles et le climat dans le Québec méridional, documents cartographiques: Tome 1. Le système hiérarchique de classification écologique du MRNQ, le milieu physique, les perturbations naturelles et le climat; Ministère des Ressources naturelles, Direction de la recherche forestière, Gouvernement du Québec: Québec, Canada, 2002.

22. Robitaille, A.; Saucier, J.-P. Land district, eco-physiographic units and areas: The landscape mapping of the Ministère des Ressources naturelles du Québec. Environ. Monit. Assess. 1996, 39, $127-148$.

23. Soil Classification Working Group. The Canadian System of Soil Classification, 3rd ed.; Agriculture and Agri-Food Canada: Ottawa, Canada, 1998.

24. Federer, C.A.; Turcotte, D.E.; Smith, C.T. The organic fraction-bulk density relationship and the expression of nutrient content in forest soils. Can. J. For. Res. 1993, 23, 1026-1032.

25. Li, Z.; Kurz, W.A.; Apps, M.J.; Beukema, S.J. Belowground biomass dynamics in the Carbon Budget Model of the Canadian Forest Sector: recent improvements and implications for the estimation of NPP and NEP. Can. J. For. Res. 2003, 33, 126-136. 
26. IPCC National Greenhouse Gas Inventories Programme. 2006 IPCC Guidelines for National Greenhouse Gas Inventories; Eggleston, H.S., Buendia, L., Miwa, K., Ngara, T., Tanabe, K., Eds.; IGES: Hayama, Japan, 2006; Volume 4.

27. Tremblay, S.; Ouimet, R.; Houle, D. Prediction of organic carbon content in upland forest soils of Quebec, Canada. Can. J. For. Res. 2002, 32, 903-914.

28. Oksanen, J.; Blanchet, F.G.; Kindt, R.; Legendre, P.; Minchin, P.R.; O’Hara, R.B.; Simpson, G.L.; Solymos, P.; Stevens, M.H.H.; Wagner, H. Vegan: Community Ecology Package, R Package Version 2.0-9, 2013. Available online: http://CRAN.R-project.org/package=vegan (accessed on 1 October 2013).

29. Pinheiro, J.; Bates, D.; Sarkar, D.; R Development Core Team. nlme: Linear and Nonlinear Mixed Effects Models, R Package Version 3.1-103, 2012. Available online: http:/CRAN.Rproject.org/package=nlme (accessed on 1 September 2013).

30. R Development Core Team. R: A language and Environment for Statistical Computing; R Foundation for Statistical Computing: Vienna, Austria, 2012.

31. Jackson, R.; Canadell, J.; Ehleringer, J.; Mooney, H.A.; Sala, O.; Schulze, E. A global analysis of root distributions for terrestrial biomes. Oecologia 1996, 108, 389-411.

32. Thuille, A.; Schulze, E.D. Carbon dynamics in successional and afforested spruce stands in Thuringia and the Alps. Glob. Change Biol. 2006, 12, 325-342.

33. Anderson, K.J.; Allen, A.P.; Gillooly, J.F.; Brown, J.H. Temperature-dependence of biomass accumulation rates during secondary succession. Ecol. Lett. 2006, 9, 673-682.

34. Ruskule, A.; Nikodemus, O.; Kasparinska, Z.; Kasparinskis, R.; Brumelis, G. Patterns of afforestation on abandoned agriculture land in Latvia. Agrofor. Syst. 2012, 85, 215-231.

35. Harmer, R.; Peterken, G.; Kerr, G.; Poulton, G. Vegetation changes during 100 years of development of two secondary woodlands on abandoned arable land. Biol. Conserv. 2001, 100, 291-304.

36. Sirami, C.; Brotons, L.; Martin, J.L. Vegetation and songbird response to land abandonment: From landscape to census plot. Diversity Distrib. 2007, 13, 42-52.

37. Bonet, A.; Pausas, J.G. Species richness and cover along a 60 -year chronosequence in old-fields of southeastern Spain. Plant Ecol. 2004, 174, 257-270.

38. Ontario Ministry Natural Resources (OMNR). A Silvicultural Guide for the Tolerant Hardwood Forest in Ontario; Queen's Printer for Ontario: Toronto, Canada, 1998.

39. Egler, F.E. Vegetation science concepts. 1. Initial floristic composition-A factor in old-field vegetation development. Vegetatio 1954, 4, 412-417.

40. Zhang, K.; Dang, H.; Tan, S.; Wang, Z.; Zhang, Q. Vegetation community and soil characteristics of abandoned agricultural land and pine plantation in the Qinling Mountains, China. For. Ecol. Manage. 2010, 259, 2036-2047.

41. Paul, K.I.; Polglase, P.J.; Nyakuengama, J.G.; Khana, P.K. Change in soil carbon following afforestation. For. Ecol. Manage. 2002, 168, 241-257.

42. Li, D.; Niu, S.; Luo, Y. Global patterns of the dynamics of soil carbon and nitrogen stocks following afforestation: A meta-analysis. New Phytol. 2012, 195, 172-181.

43. Guo, L.B.; Gifford, R.M. Soil carbon stocks and land use change: a meta analysis. Glob. Change Biol. 2002, 8, 345-360. 
44. Laganière, J.; Angers, D.A.; Paré, D. Carbon accumulation in agricultural soils after afforestation: A meta-analysis. Glob. Change Biol. 2010, 16, 439-453.

45. Shi, S.; Zhang, W.; Zhang, P.; Yu, Y.; Ding, F. A synthesis of change in deep soil organic carbon stores with afforestation of agricultural soils. For. Ecol. Manage. 2013, 296, 53-63.

46. Poeplau, C.; Don, A.; Vesterdal, L.; Leifeld, J.; van Wesemael, B.; Schumaker, J.; Gensior, A. Temporal dynamics of soil organic carbon after land-use change in the temperate zone-Carbon response functions as a model approach. Glob. Change Biol. 2011, 17, 2415-2427.

47. Guo, L.B.; Wang, M.; Gifford, R.M. The change of soil carbon stocks and fine root dynamics after land use change from a native pasture to a pine plantation. Plant Soil 2007, 299, 251-262.

48. Binkley, D.; Kaye, J.; Barry, M.; Ryan, M.G. First-rotation changes in soil carbon and nitrogen in a plantation in Hawaii. Soil Sci. Soc. Am. J. 2004, 68, 1713-1719.

49. Resh, S.C.; Binkley, D.; Parotta, J.A. Greater soil carbon sequestration under nitrogen-fixing trees compared with Eucalyptus species. Ecosystems 2002, 5, 217-231.

50. Polglase, P.J.; Paul, K.I.; Khana, P.K.; Nyakuengama, J.G.; O’Connell, A.M.; Grove, T.S.; Battaglia, M. Change in Soil Carbon Following Afforestation or Reforestation, National Carbon Accounting System Tech Report No. 20; Australian Greenhouse Office: Canberra, Australia, 2000.

51. Ellert, B.H.; Bettany, J.R. Calculation of organic matter and nutrients stored in soils under contrasting management regimes. Can. J. Soil Sci. 1995, 75, 529-538.

52. National Inventory Report 1990-2011: Greenhouse Gas Sources and Sinks in Canada. Part 3; The Canadian Government' Submission to the UN Framework Convention on Climate Change; Environment Canada: Gatineau, Canada, 2013.

53. Roy, M. Ministère des Ressources naturelles, Québec, Canada. Personal communication, 2006.

(C) 2013 by the authors; licensee MDPI, Basel, Switzerland. This article is an open access article distributed under the terms and conditions of the Creative Commons Attribution license (http://creativecommons.org/licenses/by/3.0/). 